\title{
Systemic Colonization of Potato Plants by a Soilborne, Green Fluorescent Protein-Tagged Strain of Dickeya sp. Biovar 3
}

\author{
Robert Czajkowski, Waldo J. de Boer, Henk Velvis, and Jan M. van der Wolf
}

First, second, and fourth authors: Plant Research International, P.O. Box 16, 6700 AA, Wageningen, The Netherlands; and third author: HZPC Holland, 9123 ZR Metslawier, The Netherlands. Accepted for publication 7 October 2009.

\section{ABSTRACT}

Czajkowski, R., de Boer, W. J., Velvis, H., van der Wolf, J. M. 2010. Systemic colonization of potato plants by a soilborne, green fluorescent protein-tagged strain of Dickeya sp. biovar 3. Phytopathology 100:134142.

Colonization of potato plants by soilborne, green fluorescent protein (GFP)-tagged Dickeya sp. IPO2254 was investigated by selective plating, epifluorescence stereo microscopy (ESM), and confocal laser scanning microscopy (CLSM). Replicated experiments were carried out in a greenhouse using plants with an intact root system and plants from which ca. $30 \%$ of the lateral roots was removed. One day after soil inoculation, adherence of the pathogen on the roots and the internal colonization of the plants were detected using ESM and CLSM of plant parts embedded

Dickeya spp. (syn. Erwinia chrysanthemi and/or Pectobacterium chrysanthemi) (38), together with Pectobacterium atrosepticum (formerly E. carotovora subsp. atroseptica) and $P$. carotovorum subsp. carotovorum (formerly E. carotovora subsp. carotovora), are the causative agents of potato blackleg worldwide $(7,30,31)$. Until recently, the majority of Dickeya spp. strains found in association with potato blackleg belonged to biovars 1 or 7 (D. dianthicola). These strains have a relatively low maximum growth temperature compared with other Dickeya species and seem to be more adapted to European climate conditions (18). In the last 3 years, however, Dickeya spp. strains belonging to a new biovar 3 clade, probably constituting a new species, have been frequently isolated from potato tubers in Western Europe and Israel $(19,40,42)$. The finding of this biovar 3 Dickeya spp. in seed potato tubers is associated with high incidences of potato blackleg in The Netherlands (Netherlands General Inspection Service for Agricultural Seeds and Seed Potatoes, personal communication).

In Western and Northern Europe in particular, Dickeya species are causing increasingly severe economic losses in potato crops. The costs in seed potato production resulting from Dickeya spp. caused blackleg infections are high due to rejection and declassification of seed lots (tubers) $(19,33)$.

Potato blackleg caused by Dickeya and Pectobacterium spp. is primarily a seedborne disease. Typical blackening of the stem base (blackleg) and wilting of the potato plants are always associated with rotting of the seed (mother) tuber and spreading of the inoculum (28). Symptom expression occurs when temperature and soil moisture are high, favoring multiplication of the blackleg bacteria and rotting of the seed potato (41).

Corresponding author: J. M. van der Wolf; E-mail address: Jan.vanderWolf@wur.nl

doi:10.1094/PHYTO-100-2-0134

(c) 2010 The American Phytopathological Society in an agar medium. Fifteen days post-soil inoculation, Dickeya sp. was found on average inside $42 \%$ of the roots, $13 \%$ of the stems, and $13 \%$ of the stolons in plants with undamaged roots. At the same time-point, in plants with damaged roots, Dickeya sp. was found inside $50 \%$ of the roots, $25 \%$ of the stems, and $25 \%$ of the stolons. Thirty days postinoculation, some plants showed true blackleg symptoms. In roots, Dickeya sp. was detected in parenchyma cells of the cortex, both interand intracellularly. In stems, bacteria were found in xylem vessels and in protoxylem cells. Microscopical observations were confirmed by dilution spread-plating the plant extracts onto agar medium directly after harvest. The implications of infection from soilborne inoculum are discussed.

Additional keywords: blackleg, roots, progeny tubers, vascular tissue.
For $P$. atrosepticum, it is well-established that spreading of infections within a seed lot frequently occurs during harvest and grading, particularly if rotten tubers are present harboring high densities of inoculum (9). Dispersal of $P$. atrosepticum within a seed lot can also occur during plant cultivation. During tuber decay massive amounts of bacteria are released into the soil from where they can move via free soil water up to a distance of $10 \mathrm{~m}$ (12). The bacteria can be introduced into the lenticels, which are open during heavy rainfall under anaerobic condition $(1,25)$. During harvest, a high percentage of tubers are bruised and are readily infected by contaminated equipment $(11,31)$. Bacteria present on intact tuber peel will die off rapidly, but those in lenticels, suberized wounds, and cracks may persist until the new growing season (44). It is assumed that contamination of potato tubers with Dickeya species occurs similarly.

Both lenticel contamination and infection of wounds during (post) harvest activities will primarily result in infections of the potato tuber periderm (peel). It is likely that tuber infection by Dickeya spp. can occur in a similar way.

For both Dickeya spp. and $P$. atrosepticum, however, a relatively high infection incidence is found in the stolon ends (46 ). This implies that during plant growth, internal colonization of progeny tubers via the stolons occurs more frequently than assumed. Internal infections of progeny tubers may take place in two different ways. First, bacteria can be transported directly from the mother tuber via the plant vascular system into the stems, stolons and progeny tubers (13). Second, the soilborne Dickeya sp. may also infect potato roots, from where the bacteria may further colonize the plant, including the progeny tubers. Dickeya spp., if present in soil, may enter not only the roots of the infected plant but also the roots of adjacent plants by wounds caused by soilborne pathogens and pest organisms or by natural openings which arise during lateral root formation.

The aim of this work was to investigate the ability of a representative potato strain of the new biovar 3 clade of Dickeya sp. to 
infect roots from inoculated soil and to colonize potato plants, including progeny tubers. To enable this, a green fluorescent protein (GFP)-tagged strain was generated and evaluated for growth and virulence. In greenhouse experiments, population dynamics of the pathogen in plants with an intact (undamaged) and damaged (cut) root system was studied using epifluorescence stereo microscopy (ESM), confocal laser scanning microcopy (CLSM), and dilution plating techniques.

\section{MATERIALS AND METHODS}

Bacterial strains and media used for cultivation. In all experiments a GFP-tagged strain of Dickeya sp. IPO2222 biovar 3 was used. Wild-type strain IPO 2222 was isolated from seed potato tubers cv. Melody in The Netherlands in 2007 (42). Bacteria were grown at $28^{\circ} \mathrm{C}$ for 24 to $48 \mathrm{~h}$ on tryptic soya agar (TSA) (Oxoid, Basingstoke, England), in nutrient broth (NB) (Difco, Le Pont de Claix, France), on crystal violet pectate (CVP) (16), or pectate enrichment broth (PEB) (32) prior to use. If required, growth media were supplemented with cycloheximide (Sigma Chemical, St. Louis) to a final concentration of $200 \mu \mathrm{g}$ $\mathrm{ml}^{-1}$ and with ampicillin (Sigma) to a final concentration of $150 \mu \mathrm{g} \mathrm{ml}^{-1}$.

Generation of GFP-tagged Dickeya sp. strains. Plasmid pPROBE-AT- $g f p$ (23) was used for generation of GFP-tagged Dickeya sp. IPO2254 (parental strain Dickeya sp. IPO2222). The plasmid carrying $g f p$ gene was introduced to bacterial cells by electroporation (3). Briefly, suspensions of approximately $50 \mu \mathrm{l}$ of Dickeya sp. competent cells were mixed with $0.5 \mu \mathrm{l}$ of plasmid DNA (approximately $100 \mathrm{ng} \mathrm{\mu l}^{-1}$ ) and electroshocked at $2.5 \mathrm{kV}$ for 1 to $2 \mathrm{~s}$ at $4^{\circ} \mathrm{C}$ using a Bio-Rad Gene Pulser 200/2.0 (Bio-Rad, Hercules, CA). After electroporation, cells were resuscitated for $1 \mathrm{~h}$ in $500 \mu \mathrm{l}$ of $\mathrm{NB}$ at $28^{\circ} \mathrm{C}$ with shaking. One hundred microliters of the transformed cells was plated on TSA containing ampicillin $\left(150 \mu \mathrm{g}^{-1}\right)$ and incubated for $48 \mathrm{~h}$ at $28^{\circ} \mathrm{C}$ for selection of positive transformants.

Maintenance of the pPROBE-AT-gfp plasmid in Dickeya sp. cells in vitro plant model. Maintenance of the plasmid carrying gfp gene in Dickeya sp. IPO2254 cells in planta was evaluated in a potato slice assay. Bacterial strains were grown overnight in NB supplemented with ampicillin $\left(150 \mu \mathrm{g} \mathrm{ml}^{-1}\right)(\mathrm{NBa})$ at $28^{\circ} \mathrm{C}$ with a shaking rate of $200 \mathrm{rpm}$. Bacterial suspensions were diluted in Ringer's buffer (Merck, Dormstadt, Germany) to a concentration of approximately $10^{8} \mathrm{CFU} \mathrm{ml^{-1 }}$ (optical density at $600 \mathrm{~nm}$ $\left[\mathrm{OD}_{600}\right]=0.1$ ).

Dickeya-free minitubers of cultivar Kondor (Vitrocom, Westland, The Netherlands) were rinsed with running tap water, subsequently washed twice with $70 \%$ ethanol for $5 \mathrm{~min}$, and washed twice for 1 min with demineralized water. Tubers were dried with tissue paper and cut into $0.7 \mathrm{~cm}$ transverse disk slices. One $5 \mathrm{~mm}$ deep well per slice was made using a sterile cork borer with a diameter of $5 \mathrm{~mm}$. Wells were filled with $50 \mu \mathrm{l}$ of the bacterial suspension. For disease development, slices were incubated at $28^{\circ} \mathrm{C}$ for $72 \mathrm{~h}$ in a humid box. After incubation, $200 \mathrm{mg}$ of rotten potato tissue was collected and resuspended in $2 \mathrm{ml}$ of Ringer's buffer supplemented with an antioxidant, $0.02 \%$ diethylthiocarbamic acid (Acros Organics, Geel, Belgium). Fifty microliters of the suspension was transferred to the well in a freshly prepared potato slice. Bacteria were transferred from one slice to another 10 times in total. Serial dilutions of homogenized rotten potato tissue were plated on CVP at each transfer. The total numbers of GFP-positive and GFP-negative bacterial colonies producing cavities on CVP were counted and the percentage of GFP-positive cavity-forming colonies was calculated. Three replicate potato slices were used and the experiment was repeated twice. If present, GFP-negative cavity-forming bacteria were randomly chosen at each time point and checked by a Dickeya spp.-specific polymerase chain reaction (PCR,) based on ADE1/ADE2 primers
(ADE1: 5'-GATCAGAAAGCCCGCAGCCAGAT-3', ADE2: 5'CTGTGGCCGATCAGGATGGTTTTGTCGTGC-3'), to verify the identity of bacteria (24). For this, cells were collected from a suspected colony using a sterile toothpick and resuspended in $50 \mu \mathrm{l}$ of $5 \mathrm{mM} \mathrm{NaOH}$. Suspensions were boiled for $5 \mathrm{~min}$ at $95^{\circ} \mathrm{C}$ and put on ice for 1 to $2 \mathrm{~min}$. One microliter of the cell lysate was used as a template in the Dickeya spp.-specific PCR. Amplified DNA was detected by electrophoresis in a $1.5 \%$ agarose gel in $0.5 \times$ TBE buffer stained with ethidium bromide $\left(5 \mathrm{mg} \mathrm{ml}^{-1}\right)$. The expected fragment length amplified by the ADE1/ADE2 primers for Dickeya sp. was $420 \mathrm{bp}$.

Growth of the GFP-tagged strain. To assess bacterial growth under aerobic conditions, an overnight bacterial culture with a density of ca. $10^{9}$ cells $\mathrm{ml}^{-1}$ in $\mathrm{NBa}$ was diluted 50 times in $\mathrm{NBa}$. Bacteria were grown at $28^{\circ} \mathrm{C}$ with a shaking rate of $200 \mathrm{rpm}$. Growth rate was determined by measuring the $\mathrm{OD}_{600}$ for a period of up to $25 \mathrm{~h}$.

To evaluate growth under anaerobic conditions, $5 \mathrm{ml}$ of liquid paraffin was added over $30 \mathrm{ml}$ of the bacterial suspensions in PEB, prepared as described above for growth in aerobic conditions. Samples were incubated at $28^{\circ} \mathrm{C}$ without shaking. Growth was determined by measuring the $\mathrm{OD}_{600}$ at the same time intervals as for growth in aerobic conditions.

Ability of the GFP-tagged strain to macerate tuber tissue. The ability of GFP-tagged Dickeya sp. IPO2254 to macerate potato tuber tissue was evaluated in a potato slice assay, as described for estimation of the GFP plasmid stability with some modifications. Instead of one, three wells per tuber slice were used. The diameter of rotting tissue was measured after $72 \mathrm{~h}$ incubation at $28^{\circ} \mathrm{C}$. The result was compared with that of the wild-type strain and with a water control. The experiment was repeated twice.

Growth of potato plants and soil inoculation with GFPtagged Dickeya sp. In a replicated experiment in 2008, minitubers of cultivar Kondor (Vitrocom), highly susceptible to blackleg pathogens (H. Velvis, personal communication), were planted in potting compost in 5-liter plastic pots in the greenhouse and grown at a $16 \mathrm{~h} / 8 \mathrm{~h}$ (day/night) photoperiod, at 26 to $28^{\circ} \mathrm{C}$ and $70 \%$ relative humidity. Inoculation of soil was performed 3 weeks after planting, when plants were ca. 27 to $29 \mathrm{~cm}$ high and the stolons already formed. Plants were watered up to $1 \mathrm{~h}$ before soil inoculation. The lower part of the pots (ca. 40\%) was immersed for $40 \mathrm{~min}$ in suspensions of Dickeya sp. IPO2254 containing $10^{8} \mathrm{CFU} \mathrm{ml} \mathrm{m}^{-1}$ bacteria in water, or in bacteria-free sterile water. Half an hour before soil inoculation, while avoiding disturbing the plants, $30 \%$ of roots were cut off aseptically with a knife without removing the plants from pots, from half of the number of plants. Plants with damaged and undamaged root systems were inoculated in the same way. After inoculation, plants were left unwatered for $24 \mathrm{~h}$. The greenhouse experiments were conducted in April/May and July/August 2008. In total, 36 plants were used; per replication we used 6 plants inoculated with water (control), 6 plants with intact roots inoculated with GFP-tagged Dickeya sp. IPO2254, and 6 plants with damaged roots inoculated with the same strain. As well as sampling, plants were observed weekly for development of disease symptoms.

Sampling of potato plants for CVP plating. Plants were sampled 1, 15, and 30 days postinoculation (dpi). At each time point, four plants per treatment were sampled. One gram of soil was randomly collected from each pot and separately suspended in $2 \mathrm{ml}$ of 1/4-strength Ringer's buffer (Merck) supplemented with $0.02 \%$ dieethylthiocarbamic acid (Arcos Organics). The suspended soil was shaken for $10 \mathrm{~min}$ at $100 \mathrm{rpm}$ and $100 \mu \mathrm{l}$ of the undiluted, 10 times and 100 diluted samples were plated on CVP containing cycloheximide $\left(100 \mu \mathrm{g} \mathrm{ml}^{-1}\right)$ (Sigma) and if appropriate with ampicillin $\left(150 \mu \mathrm{g} \mathrm{ml}^{-1}\right)$ (Sigma).

Per plant, the total root system was collected and processed separately. Roots were washed with water to remove soil particles, sterilized in $70 \%$ ethanol for $1 \mathrm{~min}$, washed three times 
with water for $1 \mathrm{~min}$, incubated in $1 \%$ sodium hypochlorite (commercial bleach) for $4 \mathrm{~min}$ and finally washed three times with water for $4 \mathrm{~min}$. Roots were weighed and Ringer's buffer (Merck) was added to twice the weight. Each sample was crushed in a Universal Extraction bag (BIOREBA) using a hammer. Extracts were plated as described for soil samples. To check the sterilization of root surface, the last washing water was collected, centrifuged $(8,000 \mathrm{rpm}, 10 \mathrm{~min})$, and the pellet was resuspended in $2 \mathrm{ml}$ of Ringer's buffer. Three times $100 \mu \mathrm{l}$ was plated on CVP and plates were incubated for bacterial growth and cavity formation at $28^{\circ} \mathrm{C}$ for $16 \mathrm{~h}$.

Six individual roots, three stolons, and six progeny tubers with the diameter in range between 1 to $3 \mathrm{~cm}$ from each plant were randomly chosen. These were sterilized, crushed and plated in the same way as described for total roots. Each root, stolon, and progeny tuber was processed separately.

From each plant, two or three 0.5 -cm-thick fragments from different stems cut $5 \mathrm{~cm}$ above ground level were jointly collected. The stem cuttings from each individual plant were sterilized, crushed, and plated in the same way as described for the total root system.

Microscopic observations. Sample preparation. Three roots with a length of at least $30 \mathrm{~cm}$, two stolons, and two stems were cut randomly from every plant inoculated with the GFP-tagged strain, and two leaves was also collected from a plant expressing blackleg symptoms. The cut roots, stolons and stems were washed and sterilized before microscopic observation as described for CVP plating.

ESM. Each root and stolon was cut into fragments of 1.5 to $2 \mathrm{~cm}$ long and each stem into fragments of $0.5 \mathrm{~cm}$ thick. Leaves were used without further cutting. Fragments were embedded in liquefied PT medium (32) cooled down to 45 to $50^{\circ} \mathrm{C}$ containing cycloheximide $\left(200 \mu \mathrm{g} \mathrm{ml} \mathrm{m}^{-1}\right)$ and if required with ampicillin $\left(150 \mu \mathrm{g} \mathrm{ml}^{-1}\right)$ in petri dishes. After the medium had solidified, the plates were sealed with parafilm to prevent drying and incubated for 2 days at $28^{\circ} \mathrm{C}$. Samples were examined for the presence of Dickeya sp. IPO2254 under $495 \mathrm{~nm}$ blue light using an epifluorescence stereo microscope (ESM) (Leica Wild M32 FL4) equipped with a mercury high pressure photo-optic lamp (Leica $\mathrm{Hg}$ 50W/AC) and GFP plus filter.

CLSM. Samples for the CLSM (Leica DM5500Q) were prepared in the same way as for the epifluorescence microscope. Most samples were counter-stained just before microscopic observations. For this, plant parts were washed from the agar and incubated for 0.5 to $1 \mathrm{~min}$ in propidium iodide (PI) $\left(20 \mu \mathrm{g} \mathrm{ml}^{-1}\right)$ (Invitrogen, Carlsbad, CA) solution. Samples were washed briefly in demineralized water and inspected under the microscope.

For excitation of GFP and PI, a $488 \mathrm{~nm}$ blue laser was used. For GFP, a $505 \mathrm{~nm}$ emission filter and for PI a $620 \mathrm{~nm}$ emission filter was used. Photographs were taken with a Leica Digital System (Leica) combined with a CLSM microscope using $10 \times$ and $63 \times$ water immersion objectives.

Isolation of the GFP fluorescent bacteria from the infected plant material. GFP-tagged bacteria were isolated from plant parts harboring GFP-tagged bacteria 30 dpi. Four roots, two $2 \mathrm{~cm}$ long stem cuts taken $10 \mathrm{~cm}$ above the ground level, and one leaf were cut into small pieces and incubated in $0.5 \mathrm{ml}$ of Ringer's buffer for $20 \mathrm{~min}$ with shaking, and $100 \mu \mathrm{l}$ of each suspension was plated onto TSA containing ampicillin $\left(150 \mu \mathrm{g} \mathrm{ml}^{-1}\right)$. GFPpositive colonies were collected from the plates.

Identification of GFP fluorescent bacteria by Dickeya spp.specific PCR. For characterization of the reisolated bacteria, a colony-PCR procedure was used. Cells from a suspected colony were collected from TSA with a sterile toothpick and processed in the same way as colonies sampled for the pPROBE-AT- $g f p$ plasmid stability assay.

Identification of reisolated Dickeya sp. by repetitive element PCR fingerprinting. For purification of genomic bacterial DNA, the Qiagen Genomic DNA purification Kit (Qiagen) for gramnegative bacteria was used according to the manufacturer's instructions. Repetitive element PCR fingerprinting (rep-PCR) was done on 12 randomly chosen reisolates of GFP-tagged Dickeya sp. as described before (46) using REP1R/REP2I primers (REP1R: 5'-IIIICGICGICATCIGGC-3', REP2I: 5'-ICGICTTATCIGGCCTAC-3') with the following modifications. The DNA concentration was adjusted with demineralized, sterile water to a final concentration of approximately $100 \mathrm{ng} \mathrm{ul}^{-1}$. Rep-PCR was performed in a total volume of $28 \mu \mathrm{l}$ using $6 \mathrm{U}$ of $\mathrm{Taq}$ polymerase (Roche) per reaction. Amplified DNA was analyzed by electrophoresis in a $1.5 \%$ agarose gel in $0.5 \times$ TBE buffer and stained with ethidium bromide $\left(5 \mathrm{mg} \mathrm{ml}^{-1}\right)$. The gel was run for 6 to $7 \mathrm{~h}$ at 90 to $95 \mathrm{~V}$ and at room temperature. A 1-kb ladder (Bio-Rad) was used as a size marker.

Statistical analysis. Bacterial count data were analyzed with ordinary linear regression using the statistical software package GenStat (26). To achieve approximate normality, the data were $\log$ transformed after adding a value of 1 to avoid taking logs of zero. Effects were considered to be significant at $P \leq 0.05$ and pair-wise differences were obtained using the $t$ test. Plates overgrown, due to high densities of cavity-forming bacteria on CVP, were recorded as uncountable, taking the value $10^{6} \mathrm{CFU} \mathrm{g}^{-1}$ as a likely cut-off level (censored observations). We used estimation of expected values for the censored observations based on normality assumptions as described in Schmee and Hahn (39).

Data were analyzed according to the experimental design in which two replicated greenhouse experiments were done with treatments having six replications (plants) each. The linear model considered was a complete block design with replicates as complete blocks, main effects for time and treatment and the twoway interaction between time and treatment.

\section{RESULTS}

Construction of GFP-tagged Dickeya sp. Transformation of Dickeya sp. IPO2222 with pPROBE-AT- $g f p$ resulted in 27 transformants, from which a highly fluorescent colony was selected (Dickeya sp. IPO2254). Repeated transfer of GFP-tagged bacteria onto TSA plates supplemented with ampicillin $\left(150 \mu \mathrm{g} \mathrm{ml}^{-1}\right)$ or in liquid NBa showed that the transformant expressed GFP in a stable way. The presence of pPROBE-AT- $g f p$ was proven by plasmid DNA purification and agarose gel electrophoresis (data not shown).

Maintenance of pPROBE-AT-gfp in Dickeya sp. in nonselective conditions. The stability of GFP expression in Dickeya sp. IPO2254 was evaluated in a potato slice assay. With a 3-day interval, Dickeya sp. IPO2254 was transferred from a potato slice derived from a Dickeya sp.-free minituber to a new slice, for a period of 1 month (10 times in total). During the first 9 days (three transfers) no loss of plasmid was observed. After 21 days, $95 \%$ of cells were still GFP-positive and after 30 days, $83 \%$ of the colonies still expressed GFP (data not shown). GFP-negative cavity-forming bacteria collected at each time point, were all positive in a Dickeya sp.-specific PCR (Fig. 1).

Growth of GFP-tagged Dickeya sp. GFP-tagged Dickeya sp. IPO2254 displayed similar growth characteristics as the parental wild-type strain Dickeya sp. IPO2222 under aerobic (in NB broth) and anaerobic (in PEB medium) conditions, indicating that the growth rate was not affected either by the presence of the pPROBE-AT- $g f p$ or by expression of the GFP protein (data not shown).

Tuber tissue maceration capacity of GFP-tagged Dickeya sp. The ability of the Dickeya sp. IPO2254 to macerate potato tubers tissue was investigated using a potato slice assay. After incubation of slices for 3 days at $28^{\circ} \mathrm{C}$, the diameter of the rotting tissue was not significantly different from that of the parental wild-type strain Dickeya sp. IPO2222 (data not shown). 
Colonization of potato plants followed by CVP plating. Population dynamics of Dickeya sp. IPO2254 in soil and in plants were examined by CVP plating. One day after soil inoculation the marker strain was found in all soil samples. Following a rapid decrease, populations stabilized at a low level of $10^{2}$ to $10^{3} \mathrm{CFU} \mathrm{g}{ }^{-1}$ soil during a 30 days experimental period (Fig. 2).

Densities of internal root populations of GFP-positive cavityforming bacteria in both damaged (cut) and intact (uncut) roots were high 1 day after soil inoculation $\left(10^{4}\right.$ to $\left.10^{6} \mathrm{CFU} \mathrm{g}{ }^{-1}\right)$ (Fig. 3). No statistically significant increase in densities of root populations was found during the course of the experiment, not even in plants showing visible blackleg symptoms. A significant decrease of density was found $15 \mathrm{dpi}$ in roots derived from rootdamaged plants, but the initial densities of GFP-tagged Dickeya sp. were restored after 30 days. At 1 and 30 dpi but not after 15 dpi, bacterial densities in plants with uncut roots were significantly lower than those in plants with cut roots. No visible symptoms were observed in roots.
Relatively low population densities of Dickeya sp. IPO2254 ( 1 to $1,000 \mathrm{CFU} \mathrm{\textrm {g } ^ { - 1 }}$ of plant tissue) were detected in stems, stolons, and progeny tubers of potato plants with cut and uncut roots 15 and 30 dpi (Fig. 2). No statistical differences in population densities were found in tissues derived from plants with damaged and intact roots. (Fig. 2). At 1 dpi no stolons and progeny tubers were present, whereas stems were not analyzed at $1 \mathrm{dpi}$. For stems from plants with uncut roots and stolons from cut and uncut roots a significant increase in population densities was found from 15 to 30 dpi. No GFP-tagged Dickeya sp. was found in any sample of water-inoculated control plants.

Microscopic observations of plant colonization patterns. ESM. Plant parts were analyzed with an ESM at a low magnification of 2.5 to 10 times. At 1 dpi, higher densities of Dickeya sp. IPO2254 were found on the surface of small roots (diameter: 0.25 to $0.5 \mathrm{~mm}$ ) than on the surface of larger roots (diameter: 1 to $3 \mathrm{~mm}$ ) (data not shown). At $1 \mathrm{dpi}$, bacteria were also observed inside approximately $20 \%$ of the embedded roots after disinfection.

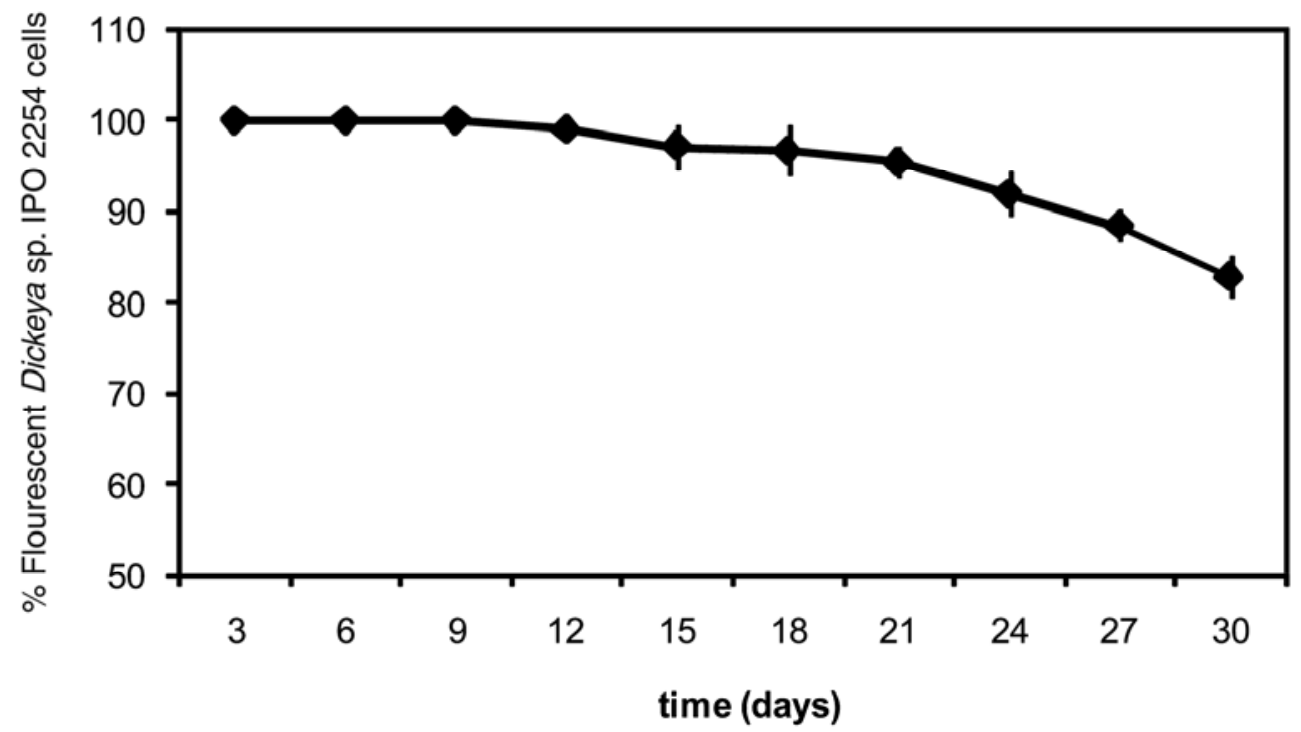

Fig. 1. Maintenance of pPROBE-AT- $g f p$ in Dickeya sp. IPO2254 during growth on potato slices. Potato slices of minitubers cv. Kondor were inoculated with $10^{8}$ $\mathrm{CFU} \mathrm{ml}{ }^{-1}$ Dickeya sp. IPO2254; slices were incubated for 3 days. Bacteria were harvested from rotten potato tissue and transferred to a fresh potato slice. Bacteria were harvested 10 times at 3-day intervals. At every transfer, serial dilutions of rotten potato tissue were plated on crystal violet pectate, and the percentage of green fluorescent protein-positive cavity-forming Dickeya sp. was calculated.

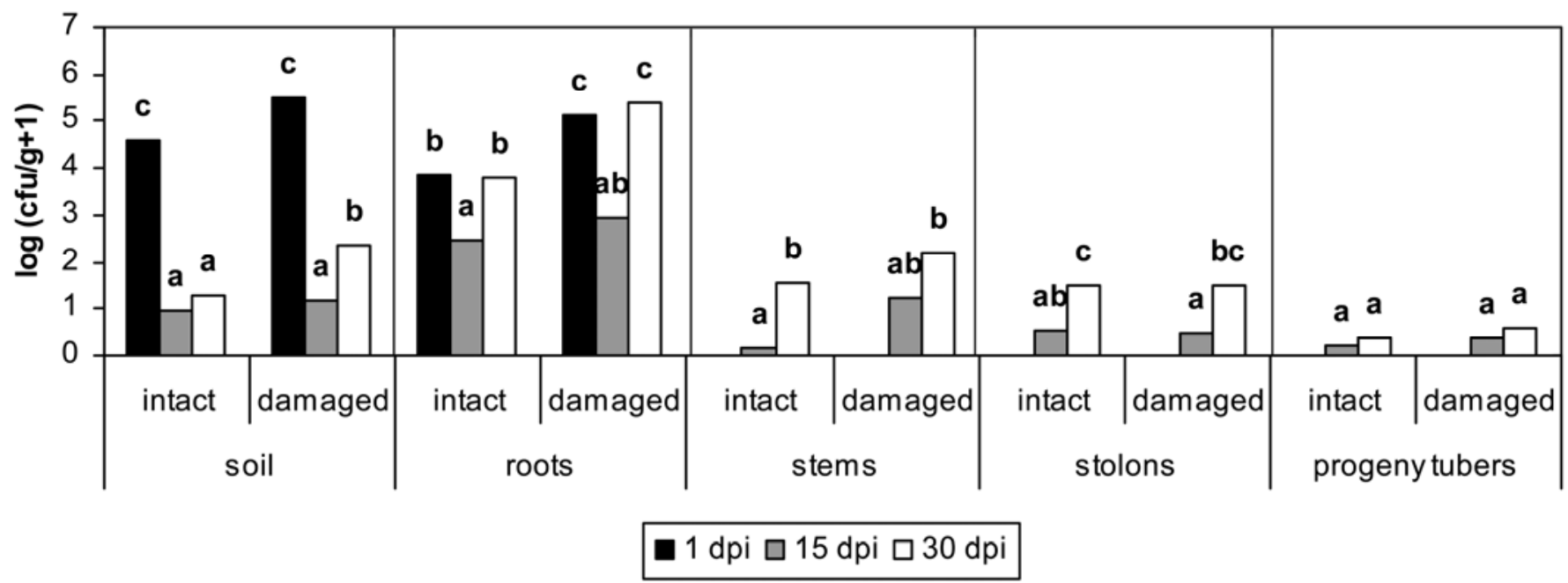

Fig. 2. Population dynamics of Dickeya spp. IPO2254 in soil, roots, stems, stolons, and progeny tubers taken from plants grown in inoculated soil. Samples were taken from plants with an undamaged (intact) and a damaged root system. Samples were surface-sterilized before extracting the bacteria. Plant and soil extracts were plated on crystal violet pectate 1, 15, and 30 days post-soil inoculation. Stem cuttings were taken $5 \mathrm{~cm}$ above the ground level. The average of the predicted values is shown from four plants per time point. Statistical analysis was done per subsample (soil $n=4$, roots $n=4$, stems $n=4$, stolons $n=12$, and progeny tubers $n=12)$. Values followed by identical characters are not significantly different $(P=0.05)$. 
A

IPO2254

unsterilized

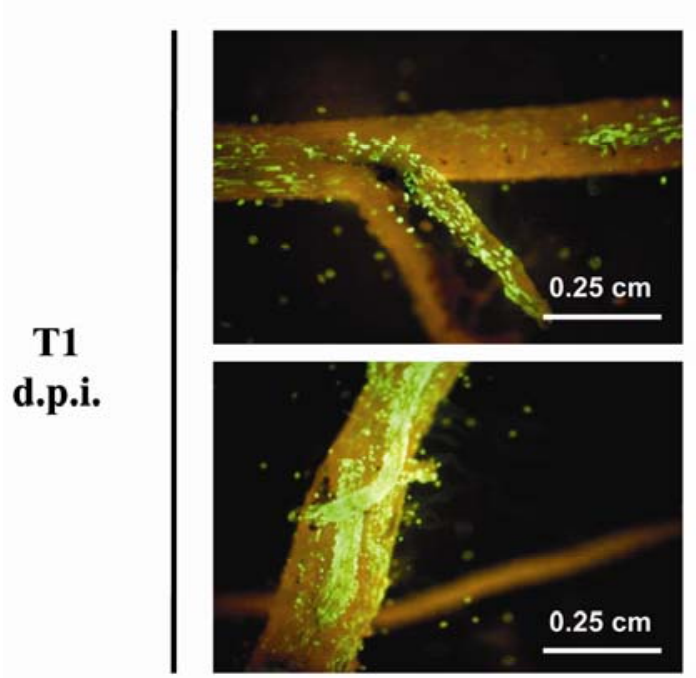

T15

d.p.i.
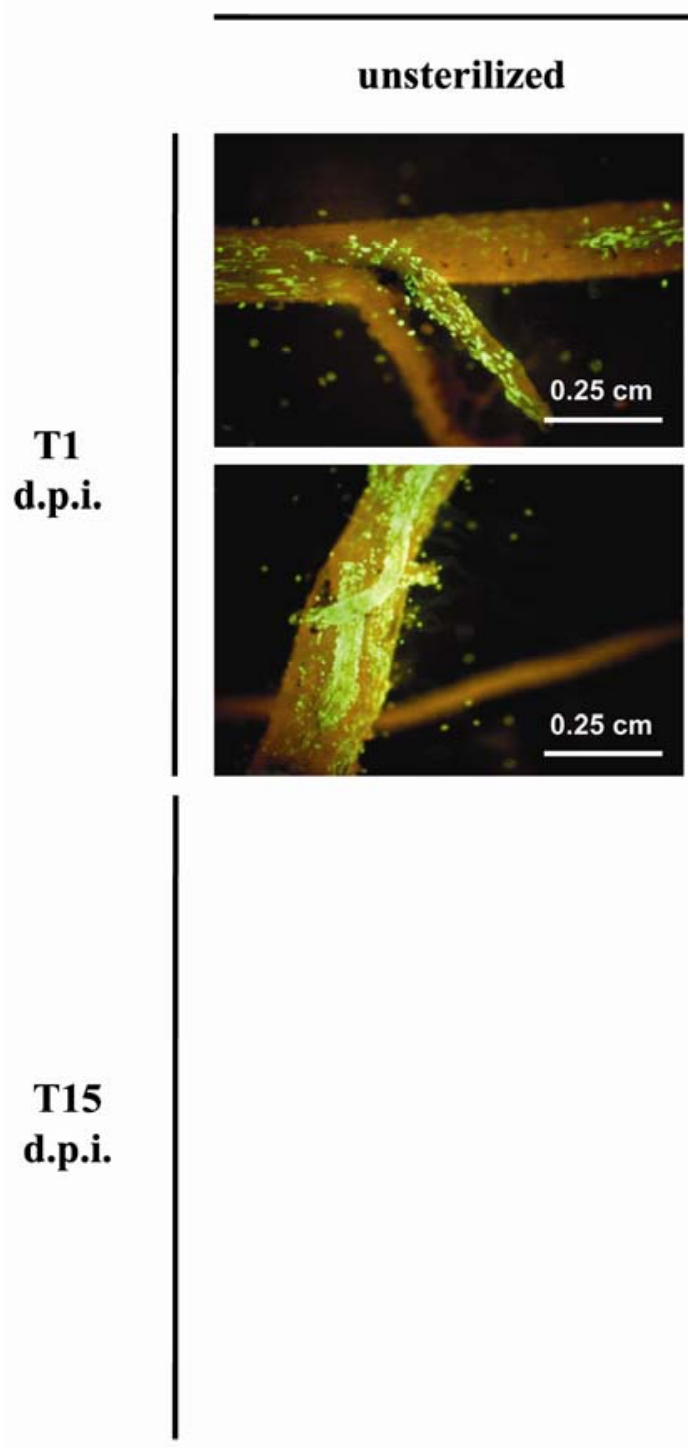

\begin{tabular}{c|} 
T.p.i. \\
T30 \\
\\
\end{tabular} sterilized
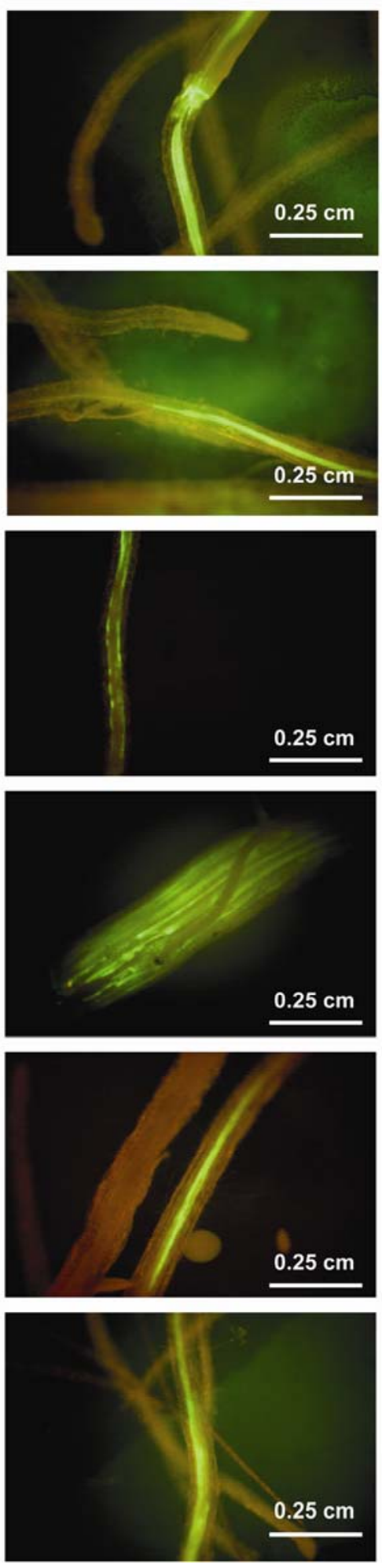

\section{control}
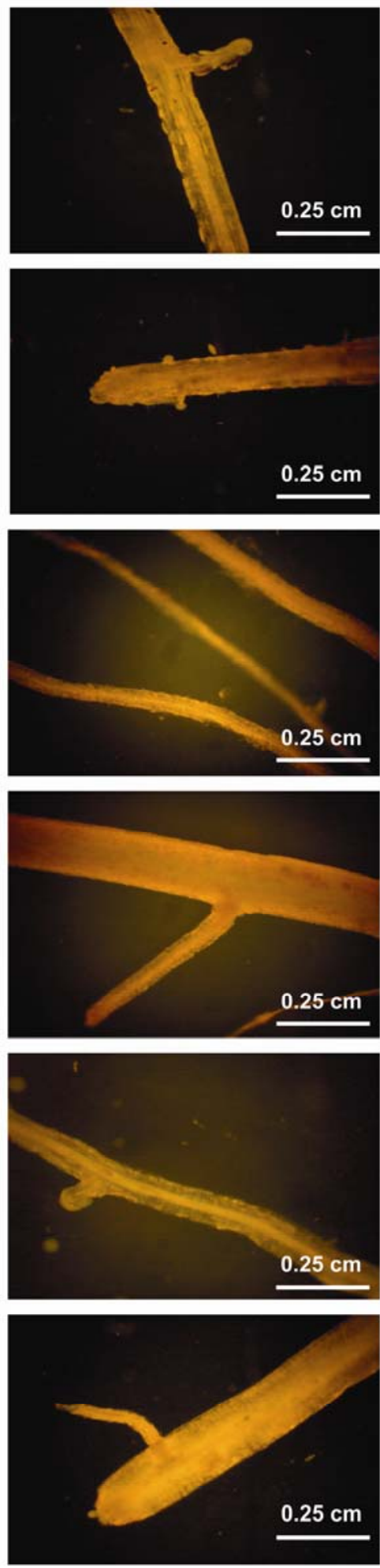

(Continued on next page)

Fig. 3. Colonization of potato roots and stems with green fluorescent protein (GFP)-tagged Dickeya sp. IPO2254 using epifluorescence stereo microscopy. Plant parts, embedded in PT agar and incubated for 1 to 2 days at $28^{\circ} \mathrm{C}$, were screened for a GFP-signal. A, Fragments of potato root. At 1 day post-soil inoculation (dpi), GFP-positive bacterial colonies on unsterilized roots were found on roots. After surface sterilization, a GFP signal was found in vascular and pith tissue of roots 1, 15, and 30 dpi. B, Cross sections of surface-sterilized potato stems embedded in PT agar. GFP signal was present in xylem and parenchyma tissue at 15 and $30 \mathrm{dpi}$, but not at $1 \mathrm{dpi}$ (data not shown). Control, samples from water-inoculated plants. 
At 15 and 30 dpi, the GFP signal was frequently found inside roots, stolons, and stem fragments taken $5 \mathrm{~cm}$ above the ground level (Fig. 3A and B). After 30 days, the GFP signal was detected in approximately $75 \%$ of the roots, $38 \%$ of the stems, and $50 \%$ of the stolons from plants with intact roots, and in $92 \%$ of roots, $50 \%$ of stems, and $50 \%$ of stolons from plants with a cut root system (Fig. 4).

CLSM. Plant parts were analyzed with a CLSM at a magnification of 640 to 1,000 times. Detailed studies on the localization of Dickeya sp. IPO2254 in plant tissues using CLSM showed that bacteria were mainly present in the vascular tissue of roots and stems. In roots, Dickeya sp. IPO2254 was found in the pith (in medulla and cortex), both inter- and intracellularly. In stems, bacterial cells were found inside and between the xylem vessels and protoxylem cells (Fig. 5).

Symptom development. No symptoms were observed in the first two weeks after soil inoculation. After 2 weeks, symptoms started to develop and after 30 days all plants grown on Dickeya sp.-infested soil showed wilting and chlorosis of the leaves, irrespective of root treatment. One plant from a cut and another from an uncut treatment showed typical blackening and soft rotting near the stem base. Control plants only expressed some chlorosis of lower leaves due to ageing (data not shown). Transsections of the stems from plants showing blackleg symptoms revealed a hollowing of the stems by degradation of pith tissue and a browning of the vascular tissue.

Characterization of GFP-expressing bacteria from infected plant tissue. Plant samples with a GFP fluorescence signal ob- served under the epifluorescence microscope were collected at $30 \mathrm{dpi}$ and were extracted and plated on TSA. Twelve green fluorescent isolates from various plant parts were selected; eight from roots, two from stems, and two from leaf material. All isolates produced typical cavities on CVP, were green fluorescent in ESM and were positive in a Dickeya sp.-specific PCR, showing the expected 420-bp PCR product (data not shown). Rep-PCR analyses showed that all fingerprints were identical to strain Dickeya sp. IPO2254 used for soil inoculation and to the parental wild-type strain Dickeya sp. IPO2222 used for GFP tagging (data not shown).

\section{DISCUSSION}

In this study we have shown for the first time that root infection with Dickeya spp. from soilborne inoculum can result in the occurrence of typical blackleg symptoms and in a systemic colonization of potato plants. Systemic colonization of Dickeya sp. in stab-inoculated root cuttings of Chrysanthemum morifolium has been reported before (27) as well as colonization of xylem vascular tissue with Dickeya spp. in naturally infected tomato plants (2). However, the colonization of intact potato roots from an inoculated soil has never been reported.

Using a GFP-tagged strain, roots were externally and internally colonized within 1 day of soil inoculation, and within 1 month, systemic spread of bacteria could be visualized in stolons and progeny tubers by dilution plating, ESM, and CLSM.
B

T15

d.p.i.

T30

d.p.i.
IPO2254
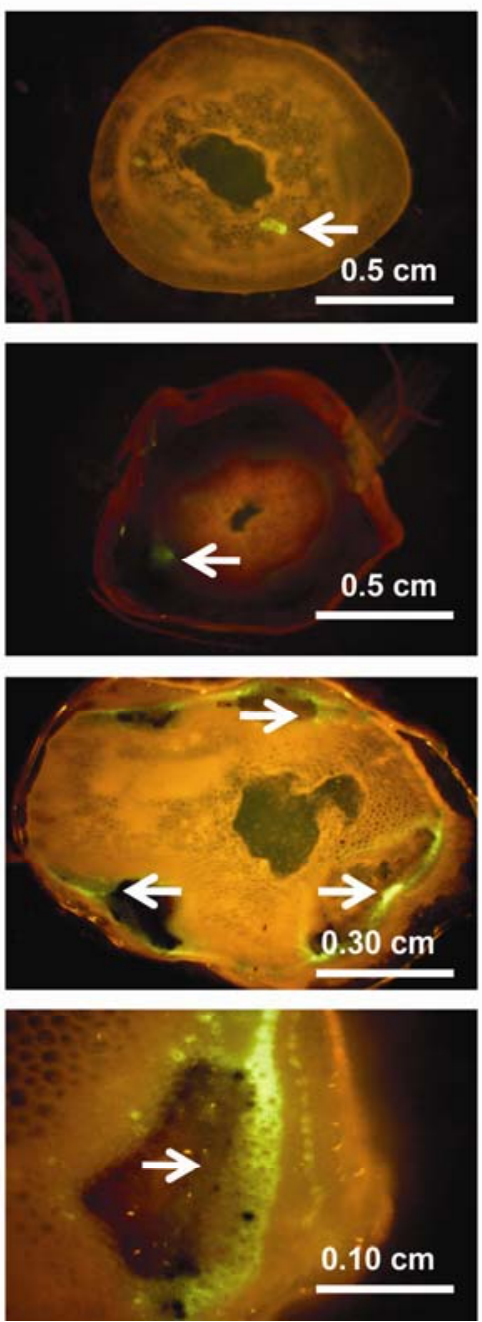

control
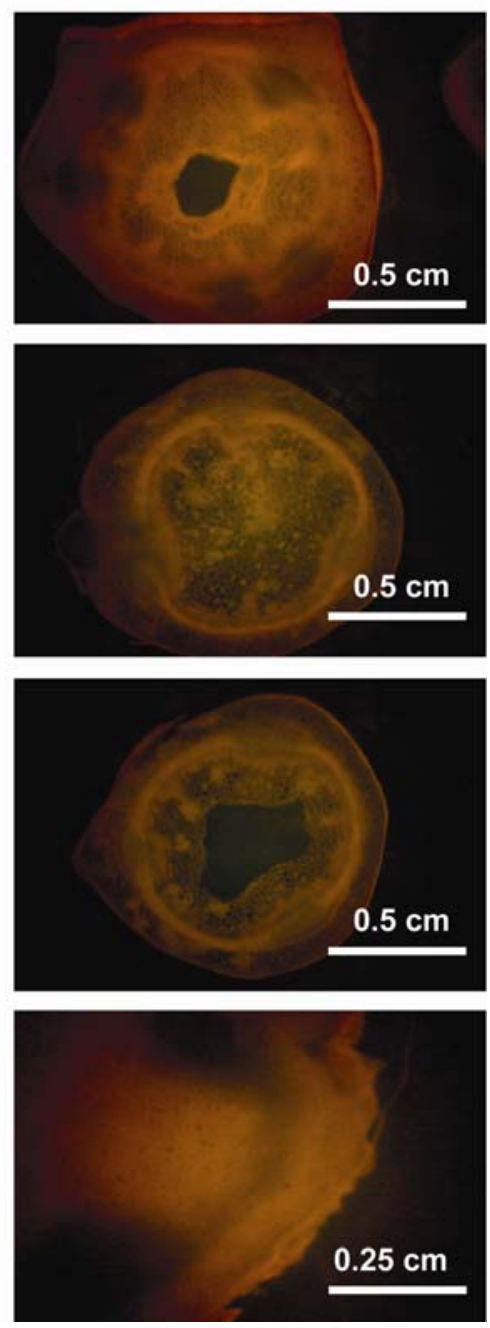

Fig. 3. (Continued from preceding page). 


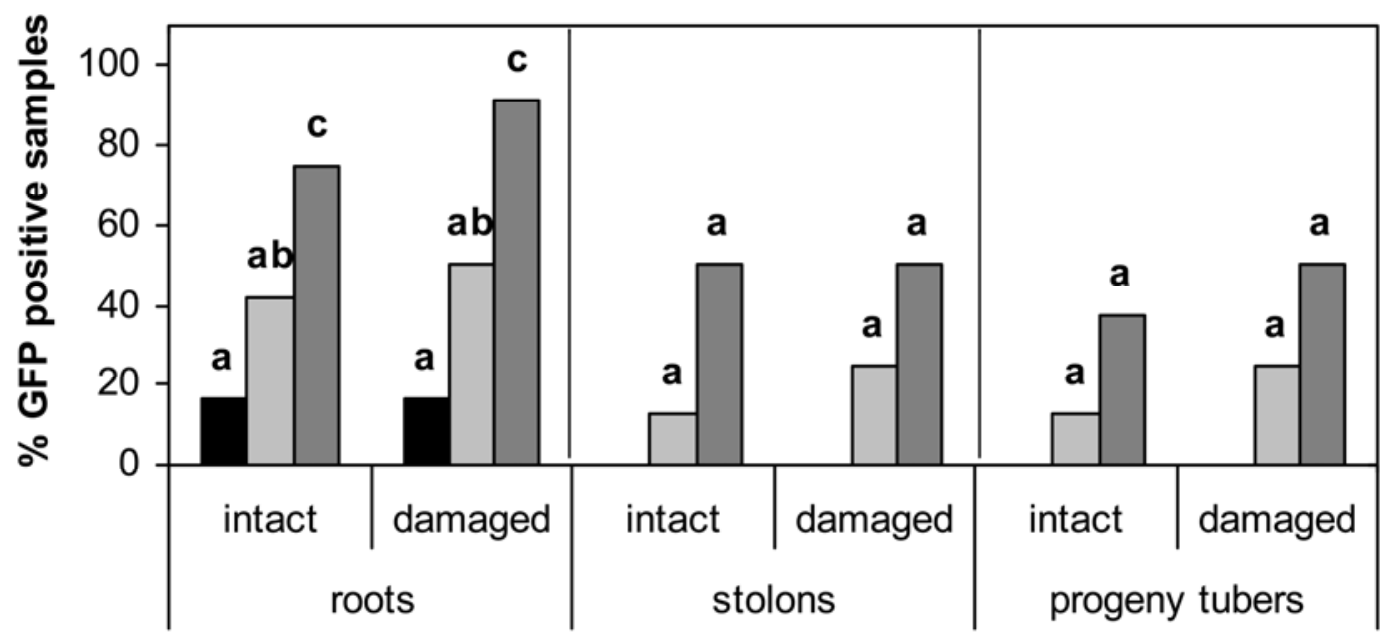

- 1 dpi $\square 15$ dpi $\square 30$ dpi

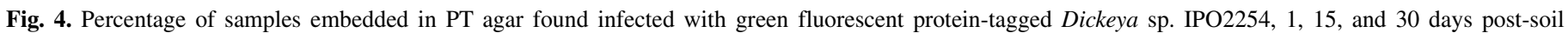

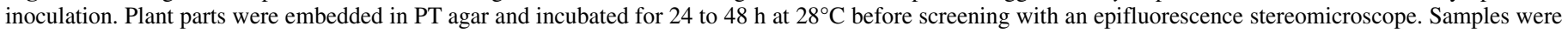

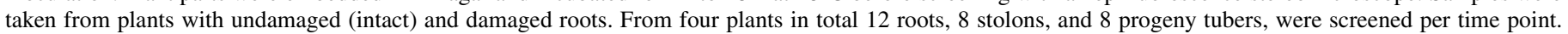
Statistical analysis was done per subsample (roots, stolons, progeny tubers). Values followed by identical characters are not significantly different $(P=0.05)$.

The identity of the GFP-positive bacteria in roots, stems, and leaves was confirmed by isolation, followed by colony PCR using Dickeya sp.-specific primers and rep-PCR analysis, showing that the fluorescence was not due to conjugative transfer of the plasmid to other bacteria or caused by autofluorescent microorganisms, such as fluorescent Pseudomonas spp., present in the same niches.

GFP possesses excellent features as a reporter protein and is broadly used for studying bacterial populations in soil and the rhizosphere, colonization of plant tissue by pathogenic bacteria and for tracing particular proteins in the cytoplasm (10,37). In our study, the GFP-tagged strain showed similar characteristics as the parental wild-type strain with respect to growth under aerobic and anaerobic conditions and in the ability to macerate potato tuber tissue. The expression of GFP did not significantly affect the important biological features of Dickeya sp. IPO 2254. This confirms the observations of other research groups using GFPtagged bacteria to monitor the destiny of bacterial cells in the environment (10).

GFP expression in Dickeya sp. during growth in plant tissue under nonselective conditions was stable. Only ca. 15\% of the cells were negative in GFP expression after a total period of 30 days and after transferring the actively growing cells 10 times to fresh potato slices. Also in other studies, pPROBE-plasmids carrying $g f p$ and various antibiotic resistance genes were stable up to 80 generations ( 80 doubling times) without any plasmid loss (23). The generation time of Dickeya spp. was determined at approximately $54 \mathrm{~min}$ in a rich medium and $80 \mathrm{~min}$ in a poor medium, respectively $(15,36)$. Assuming an average generation time of 60 min on potato slices, the pPROBE-AT- $g f p$ carrying $g f p$ gene in our study was steadily expressed in a large part of the Dickeya spp. IPO2254 population for more than 700 bacterial generations.

Low populations of GFP-tagged Dickeya sp. in potato tissue, embedded in PT medium, could be visualized with microscopical techniques after incubation. Microscopic observation of the GFPtagged bacteria in plant tissue directly after harvest was often difficult due to the relatively low cell densities. Therefore, the embedded tissue was incubated for 24 to $48 \mathrm{~h}$, enabling the bacterial cells to multiply. In this way we were able to monitor specifically culturable cells even if initial population densities were low.
Our microscopic observations may suggest that Dickeya sp. shares the same pattern as other root invading bacteria (21), comprising three stages. In the first stage, bacteria colonize the surface of lateral roots and junctions between the lateral and main roots. In the second stage, bacteria penetrate the roots and establish infection of the cortex, and in stage three, they move into parenchyma cells of the pith and into xylem vessels of the stems, from where they can easily spread towards distantly located plant parts. Such colonization was observed both for Ralstonia solanacearum, a gram-negative vascular plant pathogen (45) and for a nitrogen-fixing gram-positive Bacillus megaterium (21).

Root colonization from soilborne inoculum was found irrespective if roots were damaged or not, indicating that Dickeya sp. enters via natural openings that occur during main and lateral root formation. In general, small but significant differences were found between incidences in infected tissues from plants with intact and damaged roots. It has been reported that both plantpathogenic bacteria, such as $R$. solancearum, and endophytic bacteria can enter plant roots via natural openings $(14,17,35)$. In our study, higher numbers of GFP-tagged Dickeya sp. were found on the surface of lateral roots than on the surface of primary roots 1 day post-soil inoculation (data not shown). Similar results have been reported in root cuttings grown under in vitro conditions, where Dickeya spp. was predominantly found near natural openings created during lateral root formation (43).

Infection of soil with Dickeya spp. can also occur via other routes. Dickeya spp. bacteria can be released from rotten tubers or from an infected root system. The motile bacteria can migrate via free water in soil up to a distance of $10 \mathrm{~m}$ (12). Continuous infection of soils can occur during rainfall, if high numbers of bacteria are released into the soil from decaying tubers. Soil may also be infected from infected haulms after haulm destruction, as they can contain large numbers of cells which may contaminate the soil after rainfall (29). Finally, soilborne inoculum of Dickeya spp., a broad host range pathogen, may originate from other infected hosts, including crops grown in rotation with potato and/or weeds $(8,22)$.

The risk of infection of a potato crop from soilborne inoculum will be dependent on the survival of the bacteria in the soil. Survival of Dickeya spp. in soil seems to be relatively short with a maximum period of 6 months $(20,34)$. In our studies, a 1,000-fold 


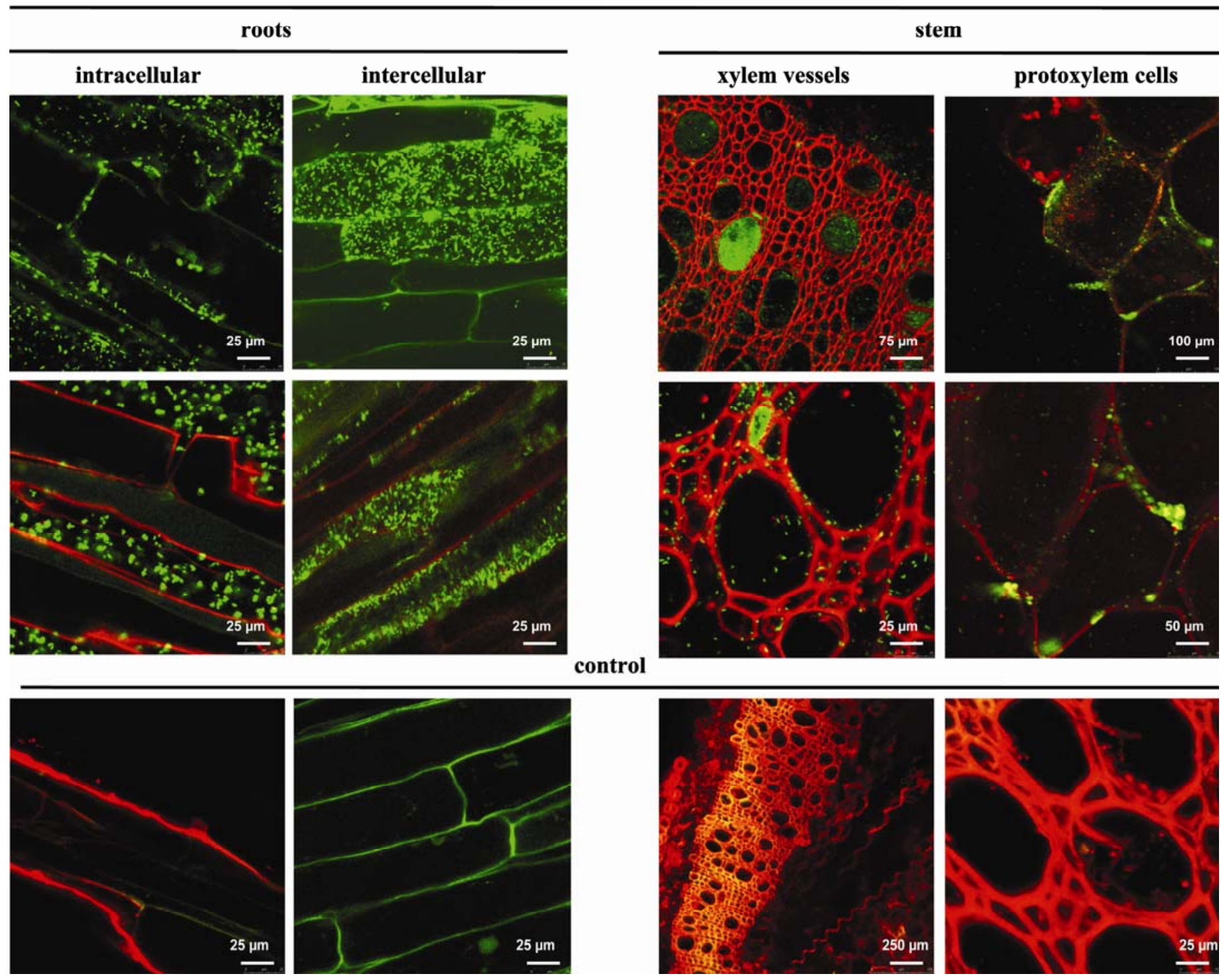

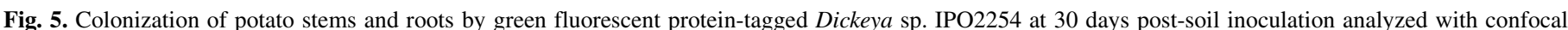

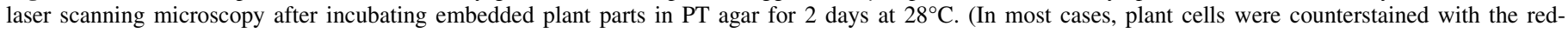
fluorescing dye propidium iodide.)

decrease in populations was found within 15 days. However, Dickeya sp. could survive at low densities of ca. $10^{2}$ to $10^{3} \mathrm{CFU}$ per gram of soil for 30 days. These densities may be sufficient to establish an infection when the conditions promote plant colonization. Moreover, it cannot be excluded that Dickeya spp. may survive longer in plant debris of host plants as it was reported for closely related $P$. carotovorum (5).

Systemic colonization of potato plants will be dependent on various factors such as potato cultivar, Dickeya species, initial inoculum present, soil moisture, soil type, temperature, and $\mathrm{pH}$. In our experiments, all plants showed symptoms, of which two plants had a typical blackening of the stem base, wilting, chlorosis and necrosis of plant tissue. In the glasshouse, conditions were highly favorable for disease development. The potato cultivar Kondor is highly susceptible to blackleg-causing pathogens $(\mathrm{H}$. Velvis, unpublished data). The Dickeya sp. biovar 3 strain used is highly virulent, causes high blackleg incidences in the field and has been dominantly present in seed potatoes in several European countries in the past 5 years $(19,40,42)$. The temperature in the glasshouse was high, favoring bacterial proliferation and symptom expression. Roots were submerged for $40 \mathrm{~min}$ in a bacterial suspension, probably long enough to create low oxygen condi- tions that can impair the host defense (29). Field studies are required to further assess the risks of systemic colonization of plants via soilborne inoculum.

In general, these results suggest that systemic colonization of potato plants from contaminated soils can be highly significant in the epidemiology of potato blackleg caused by Dickeya spp. Progeny tubers can be infected systemically at the stolon end before harvest, limiting the possibility of controlling blackleg during harvest and postharvest. To further estimate the role of stolon end infection, the frequency of blackleg development from infected stolon ends relative to infected periderm needs to be investigated.

\section{ACKNOWLEDGMENTS}

We thank I. Yedidia (Department of Ornamental Horticulture, ARO, Volcani Center, Israel) for providing the pPROBE-AT- $g f p$ plasmid, P. S. van der Zouwen and M. Fiers (PRI, The Netherlands) for technical help, M. Perombelon (ex SCRI, UK) for the helpful discussion, and L. J. Hyman (ex SCRI, UK) for her editorial work of the manuscript. The project was financed by the Dutch Ministry of Agriculture, Nature and Food Quality (programme BO-06-004). 


\section{LITERATURE CITED}

1. Adams, M. J. 1975. Potato tuber lenticels: Susceptibility to infection by Erwinia carotovora var. atroseptica and Phytophthora infestans. Ann. Appl. Biol. 79:275-282.

2. Alivizatos, A. S. 1985. Bacterial wilt of tomato in Greece caused by Erwinia chrysanthemi. Plant Pathol. 34:638-639.

3. Calvin, N. M., and Hanawalt, P. C. 1988. High-efficiency transformation of bacterial cells by electroporation. J. Bacteriol. 170:2796-2801.

4. Czajkowski, R., Grabe, G., and van der Wolf, J. M. 2009. Distribution of Dickeya spp. and Pectobacterium carotovorum subsp. carotovorum in tubers of naturally infected seed potatoes. Eur. J. Plant Pathol. DOI: 10.1007/s10658-009-9480-9.

5. De Boer, S. H., Allan, E., and Kelman, A. 1979. Survival of Erwinia carotovora in Wisconsin soils. Am. J. Potato Res. 56:243-252.

6. De Boer, S. H. 2002. Relative incidence of Erwinia carotovora subsp. atroseptica in stolon end and peridermal tissue of potato tubers in Canada. Plant Dis. 86:960-964.

7. De Haan, E., Dekker-Nooren, T., van den Bovenkamp, G., Speksnijder, A., van der Zouwen, P., and van der Wolf, J. 2008. Pectobacterium carotovorum subsp. carotovorum can cause potato blackleg in temperate climates. Eur. J. Plant Pathol. 122:561-569.

8. Dickey, R. S. 1980. Erwinia chrysanthemi: Reaction of eight plant species to strains from several hosts and to strains of other Erwinia species. Phytopathology 71:23-29.

9. Elphinstone, J. G., and Perombelon, M. C. M. 1986. Contamination of progeny tubers of potato plants by seed- and leaf-borne Erwinia carotovora. Potato Res. 29:77-93.

10. Errampalli, D., Leung, K., Cassidy, M. B., Kostrzynska, M., Blears, M., Lee, H., and Trevors, J. T. 1999. Applications of the green fluorescent protein as a molecular marker in environmental microorganisms. J. Microbiol. Meth. 35:187-199.

11. Graham, D., and Hardie, J. 1971. Prospects for control of potato blackleg disease by the use of stem cuttings. Proc. Br. Insectic. Fungic. Conf. 6th. $1: 219-236$.

12. Graham, D. C., and Harper, P. C. 1967. Potato blackleg and tuber soft rot. Scott. Agric. 48:68-74.

13. Helias, V., Andrivon, D., and Jouan, B. 2000. Development of symptoms caused by Erwinia carotovora sp. atroseptica under field conditions and their effects on the yield of individual potato plants. Plant Pathol. 49:2332.

14. Huang, Q., and Caitilyn, A. 2000. Polygalacturonases are required for rapid colonization and full virulence of Ralstonia solanacearum on tomato plants. Physiol. Mol. Plant Pathol. 57:77-83.

15. Hugouvieux-Cotte-Pattat, N., and Baudouy, J. R. 1994. Molecular analysis of the Erwinia chrysanthemi region containing the $k d g A$ and $z w f$ genes. Mol. Microbiol. 11:67-75.

16. Hyman, L. J., Sullivan, L., Toth, I. K., and Perombelon, M. C. M. 2001. Modified crystal violet pectate medium (CVP) based on a new polypectate source (Slendid) for the detection and isolation of soft rot erwinias. Potato Res. 44:265-270.

17. James, E. K., Gyaneshwar, P., Mathan, N., Barraquio, W. L., Reddy, P. M., Iannetta P. P. M., Olivares, L. F., and Ladha, J. K., 2002. Infection and colonization of rice seedlings by the plant growth-promoting bacterium Herbaspirillum seropedicae Z67. Mol. Plant-Microbe Interact. 15:894906.

18. Janse, J. D., and Ruissen, M. A. 1988. Characterization and classification of Erwinia chrysanthemi strains from several hosts in The Netherlands. Phytopathology 78:800-808.

19. Laurila, J., Ahola, V., Lehtinen, A., Joutsjoki, T., Hannukkala, A., Rahkonen, A., and Pirhonen, M. 2008. Characterization of Dickeya strains isolated from potato and river water samples in Finland. Eur. J. Plant Pathol. 122:213-225.

20. Lim, W. H. 1975. The survival of Erwinia chrysanthemi in peat and mineral soil. Mardi Res. Bull. 3:20-23.

21. Liu, X., Zhao W., and Chen, S. 2006. Colonization of maize and rice plants by strain Bacillus megaterium C4. Curr. Microbiol. 52:186-190.

22. Ma, B., Hibbing, M., Hye-Sook, E., Reedy, K. R., Yedidia, M. I., Breuer, J., Breuer, J., Glasner, J., Perna, D. N. T., Kelman, A., and Charkowski, A. 2007. Host range and molecular phylogenies of the soft rot enterobacterial genera Pectobacterium and Dickeya. Phytopathology 97:1150-1163.

23. Miller, W. G., Leveau, J. H. J., and Lindow, S. E. 2000. Improved $g f p$ and inaZ broad-host-range promoter-probe vectors. Mol. Plant-Microbe Interact. 13:1243-1250.

24. Nassar, A., Darrasse, A., Lemattre, M., Kotoujansky, A., Dervin, C., Vedel, R., and Bertheau, Y. 1996. Characterization of Erwinia chrysanthemi by pectinolytic isozyme polymorphism and restriction fragment length polymorphism analysis of PCR-amplified fragments of pel genes. Appl. Environ. Microbiol. 62:2228-2235.

25. Nielsen, L. 1978. Erwinia species in the lenticels of certified seed potatoes. Am. J. Potato Res. 55:671-676.

26. Payne, R. W., Harding, S. A., Murray, D. A., Soutar, D. M., Baird, D. B., Glaser, A. I., Channing, I. C., Welham, S. J., Gilmour, A. R., Thompson, R., and Webster, R. 2008. GenStat Release 11 Reference Manual, Part 2 Directives. VSN International, Hemel Hempstead, UK.

27. Pennypacker, B. W., Smith, C. M., Dickey, R. S., and Nelson, P. E. 1981. Histopathology of a symptomless chrysanthemum cultivar infected by Erwinia chrysanthemi or E. carotovora subsp. carotovora. Phytopathology 71:141-148.

28. Perombelon, M. C. M. 1974. The role of the seed tuber in the contamination by Erwinia carotovora of potato crops in Scotland. Potato Res. 17:187-199.

29. Perombelon, M. C. M. 1982. The impaired host and soft rot bacteria. Pages 56-69 in: Phytopathogenic Prokaryotes. M. S. Mount and G. H. Lacy, eds. Academic Press, New York.

30. Perombelon, M. C. M. 1992. Potato blackleg: Epidemiology, hostpathogen interaction and control. Neth. J. Plant Pathol. 98(2Supplement):135-146.

31. Perombelon, M. C. M., and Salmond, G. P. C. 1995. Bacterial soft rots. Pages 1-20 in: Prokaryotes. Vol. I. U. Singh and R. Kohmoto, eds. Pergamon Press, Oxford, UK.

32. Perombelon, M. C. M., and van der Wolf, J. M. 2002. Methods for the detection and quantification of Erwinia carotovora subsp. atroseptica (Pectobacterium carotovorum subsp. atrosepticum) on potatoes: A laboratory manual. Scotish Crop Research Institute, Dundee, Scotland.

33. Prins, H., and Breukers, A., 2008. In de puree? De gevolgen van aantasting door Erwinia voor de pootaardappelsector in kaart gebracht. LEI, Den Haag. The Netherlands.

34. Rangarajan, M., and Chakravarti, B. P. 1970. Studies on the survival of corn stalk rot bacteria. Plant Soil 33:140-144.

35. Reinhold-Hurek, B., and Hurek, T. 1998. Interactions of gramineous plants with Azoarcus spp. and other dizotrophs: Identification, localization and perspectives to study their function. Crit. Rev. Plant Sci. 17:29-54.

36. Rincon-Enriquez, G., Crete, P., Barras, F., and Py, B. 2008. Biogenesis of $\mathrm{Fe} / \mathrm{S}$ proteins and pathogenicity: IscR plays a key role in allowing Erwinia chrysanthemi to adapt to hostile conditions. Mol. Microbiol. 67:1257-1273.

37. Rosochacki, S. J., and Matejczyk, M. 2002. Green fluorescent protein as a molecular marker in microbiology. Acta Microbiol. Pol. 51:205-216.

38. Samson, R., Legendre, J. B., Christen, R., Fischer-Le Saux, M., Achouak, W., and Gardan, L. 2005. Transfer of Pectobacterium chrysanthemi (Burkholder et al. 1953) Brenner et al. 1973 and Brenneria paradisiaca to the genus Dickeya gen. nov. as Dickeya chrysanthemi comb. nov. and Dickeya paradisiaca comb. nov. and delineation of four novel species, Dickeya dadantii sp. nov., Dickeya dianthicola sp. nov., Dickeya dieffenbachiae sp. nov. and Dickeya zeae sp. nov. Int. J. Syst. Evol. Microbiol. 55:1415-1427.

39. Schmee, J., and Hahn, G. J. 1979. A simple method for regression analysis with censored data. Technometrics 21:417-432.

40. Slawiak, M., Beckhoven, J. R. C. M., Speksnijder, A. G. C. L., Czajkowski, R., Grabe, G., and van der Wolf, J. M. 2009. Biochemical and genetical analysis reveal a new clade of biovar 3 Dickeya spp. strains isolated from potato in Europe. Eur. J. Plant Pathol. DOI: 10.1007/s 10658-009-9479-2.

41. Stead, D. 1999. Bacterial diseases of potato: Relevance to in vitro potato seed production. Potato Res. 42:449-456.

42. Tsror, L., Erlich, O., Lebiush, S., Hazanovsky, M., Zig, U., Slawiak, M., Grabe, G., van der Wolf, J. M., and van de Haar, J. J. 2008. Assesment of recent outbreaks of Dickeya sp. (syn. Erwinia chrysanthemi) slow wilt in potato crops in Israel. Eur. J. Plant Pathol. 123:311-320.

43. Underberg, H., and Vuurde, J. W. L. 1989. In situ detection of Erwinia chrysanthemi on potato roots using immunofluorescence and immunogold staining. Pages 937-962 in: Proc. 7th Int. Conf. Plant Pathol. Bact. Akademiai Kiado, Budapest, Hungary.

44. Van Vuurde, J. W. L., and de Vries, P. M. 1994. Population dynamics of Erwinia carotovora subsp. atroseptica on the surface of intact and wounded seed potatoes during storage. J. Appl. Bacteriol. 76:568-575.

45. Vasse, J., Genin, S., Frey, P., Boucher, C., and Brito, B. 2000. The hrpB and $h r p G$ regulatory genes of Ralstonia solanacearum are required for different stages of the tomato root infection process. Mol. Plant-Microbe Interact. 13:259-267.

46. Versalovic, J., Schneider, M., de Bruijn, F. J., and Lupski, J. R., 1994. Genomic fingerprinting of bacteria using repetitive sequence-based polymerase chain reaction. Method Mol. Cell. Biol. 5:25-40. 